\title{
VIBROACOUSTIC STUDY OF POWERTRAINS OPERATED IN CHANGING CONDITIONS BY MEANS OF ORDER TRACKING ANALYSIS
}

\section{DIAGNOSTYKA WIBROAKUSTYCZNA ZESPOŁÓW NAPĘDOWYCH PRACUJĄCYCH W ZMIENNYCH WARUNKACH Z WYKORZYSTANIEM ANALIZY RZĘDÓW}

\begin{abstract}
Very often, simple signal metrics, such as Root Mean Square, Kurtosis or Crest Factor are used to characterize the operating condition of industrial machinery. Variations in the values of these metrics are often thought to be indicative of the presence of a developing fault. However, it may also be observed that often these parameters are also dependent on the operating conditions of the machine. This paper proposes a method for the assessment of the technical condition of powertrain components taking into consideration changes to system loading and rotational speed. The method allows diagnostic parameters to be determined which are independent of the speed or the loading of the power train. This decoupling allows robust condition indicators, independent of operating state, to be determined. The method proposed is based on the order analysis of vibroacoustic signals, properly scaled in terms of amplitude for the loading and rotational speed. A diagnostics experiment was carried out using a laboratory test facility comprised of a motor, a parallel shaft gearbox and a worm gear. Shaft misalignment was simulated for various components at various rotational speeds of the input shaft and different system load conditions.
\end{abstract}

Keywords: order analysis, vibroacoustics, diagnostics, condition monitoring.

\begin{abstract}
Do określenia stanu technicznego maszyn przemysłowych bardzo często używane sa podstawowe parametry sygnału, takie jak wartość skuteczna (RMS), kurtoza czy współczynnik szczytu. Zmiana tych parametrów w większości przypadków traktowana jest jako zmiana stanu technicznego maszyn. Jednak w niektórych przypadkach może być ona zwiąana również ze zmianq warunków pracy maszyny. W artykule zaproponowano metodę oceny stanu technicznego elementów napędu uwzględniajaca zmianę obciążenia układu oraz zmianę prędkości obrotowej. Metoda ta umożliwia wyznaczenie parametrów diagnostycznych, które sq niezależne od zmiany prędkości oraz obciażenia układu napędowego. Pozwala to na wyznaczenie wartości krytycznych tych parametrów niezależnych od warunków pracy maszyny. Zaproponowana metoda oparta jest na analizie rzędów sygnału wibroakustycznego odpowiednio przeskalowanej amplitudowo ze względu na obciążenie oraz prędkość obrotową.W celu weryfikacji metody przeprowadzono eksperyment diagnostyczny na stanowisku laboratoryjnym, sktadajacym się z silnika, przektadni walcowej oraz przekładni ślimakowej. Zasymulowana została niewspółosiowość wałów dla różnych podzespołów dla różnych prędkości obrotowych wału wejściowego i różnych obciążeń układu.
\end{abstract}

Słowa kluczowe: analiza rzędów, wibroakustyka, diagnostyka, monitorowanie stanu technicznego.

\section{Introduction}

The complexity of production systems motivates the constant monitoring of the technical condition of machines which contribute to the efficient operation of the process, and where a breakdown of any one component can lead to considerable economic loss due to unscheduled downtime. Utilizing monitoring systems which enable the evaluation of the technical condition of the machine, the maintenance and overhaul dates can be planned in advance, particularly for equipment that is required to perform at high reliability levels [3]. A considerable number of industrial devices operate under varying conditions, i.e. at variable loads and rotational speeds thus requiring the methods of non-stationary signal analysis to be applied. Research into methods for analysing non-stationary signals generated by rotating machinery began in the 1980 s $[2,9,13]$. These approaches typically involve synchronous diagnostic signal sampling, where the sampling frequency depends on the rotational speed signal of the machine being examined. Recently, diagnostics methods have been developed which involve synchronising diagnostic signals with rotational speed by means of subsampling methods $[4,8,11]$, the Gabor transform [12, 14] or tacholess order tracking analysis [17].

This paper focuses on the development of a method for evaluating the technical condition of powertrains, based on an order tracking analysis which also takes into account both rotational speed varia- 
tions and system loading. The method was developed in such a manner that it could be implemented in a continuous monitoring system. With order tracking analysis, characteristic orders can be monitored whose indices do not change with the rotational speed, thus making it possible to automate the damage detection process more effectively. However, the variation in loading changes the amplitude of individual vibroacoustic signal orders, and different methods can be found to eliminate the effect of loading change on the vibroacoustic signal, such as a method involving the pseudo-Wigner-Ville distribution [16] and a method based on the determination of linear dependence between the operating conditions and the diagnostic features [1]. This paper focuses on a method for diagnosing technical condition of powertrains operating in different loading and rotational speed ranges. This method involves scaling characteristic orders based on characteristic obtained by recording vibration signals and the rotational speed during motor start-up and shut-down procedures. This characteristic is relatively easy to achieve, even in industrial conditions. In addition, the method does not require the assumption of linearity between load and analysed diagnostic parameters. The paper is structured as follows. In Section 2 the testing facility is described. A description of the experimental rig is presented in section 3 . The method for evaluating the technical condition and the results of analysis are described in section 4 .

\section{Testing facility description}

Proper alignment of individual machines is one of the most important considerations when assembling powertrains. Assembly imperfections can reduce the effectiveness and lead to damage of machine components such as bearings, gears, couplings and seals [6]. A laboratory testing rig was designed that allows diagnostic studies covering the misalignment of shafts of individual components to be conducted at different load conditions and rotational speeds of the powertrain. The rig was installed on a specially prepared platform enabling stable mounting of individual components to the base. The facility design allowed individual components to be positioned by sliding or rotating them in specially designed platform guides, enabling quick adjustment of shaft misalignment between the motor, cylindrical gear and worm gear, without the need to remove individual components. The selection of components was determined by their widespread use in industry. Multistage gears with additional cylindrical stage are used in applications requiring low speed, such as: dryers, dehydrators, rotary tables, welding turntables, rail turntables. The rig design and operating principle is shown in the diagram presented in Fig. 1 and 2.

The testing rig was driven by an electric motor $(1-$ Fig. 2$)$ with designation Sg90S2 and ratings: power output $1.5 \mathrm{~kW}, \mathrm{n}=2840 \mathrm{rpm}$. The motor was controlled with an inverter (2 - Fig. 2) with designation FR-S520SE-1.5K-EC. The electric motor drive shaft was coupled directly with a coupling (3 - Fig. 2) with designation ROTEX 19, with a single-stage gearbox (4 - Fig. 2) with designation SK11EW and nominal parameters: torque $\mathrm{M}=6.9 \mathrm{Nm}$, gear ratio $\mathrm{i}=1.35$. The gearbox was comprised of two helical gears with tooth numbers $z_{1}=26$, $\mathrm{z}_{2}=35$. The driving force was transmitted with a rigid pin coupling (5 - Fig. 2) from the gearbox (4 - Fig. 2) to the worm gear (6 - Fig. 2) with designation $8 \mathrm{CN} 20$ and ratings: power output $\mathrm{N}=5.5 \mathrm{HP}(4.045$ $\mathrm{kW}$ ), gear ratio $\mathrm{i}=25$. The worm gear unit contained a multi-thread worm $\mathrm{z}_{1}=2$ and a worm wheel $\mathrm{z}_{2}=50$. The cylindrical gear was coupled via a rigid pin coupling with the worm gear. The output shaft of the worm gear (6 - Fig. 2$)$ was connected with a disc brake (7 - Fig. 2 ) that provided loading to the entire powertrain. The rotational speed of the motor output shaft was measured with a 2981 - CCLD laser tacho probe (8 - Fig. 2).

Accelerometers were mounted in pre-drilled holes in the motor body, cylindrical gear and the worm gear. The arrangement and direction of acceleration measurements is marked in the Fig. 2, where the

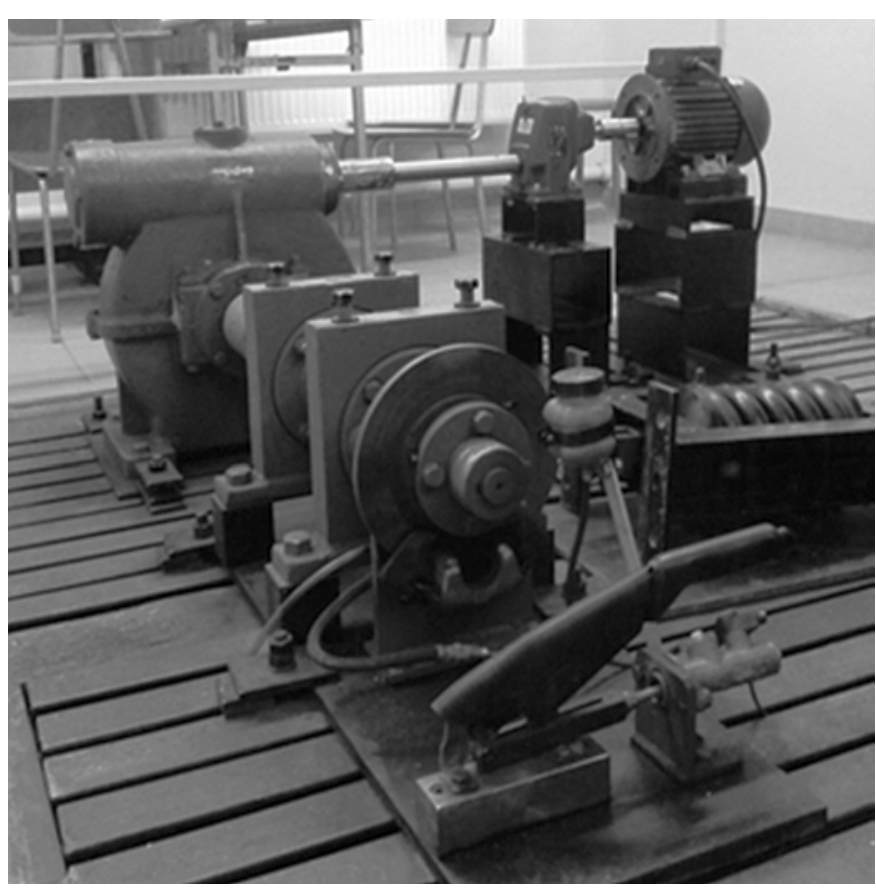

Fig. 1. Testing rig view

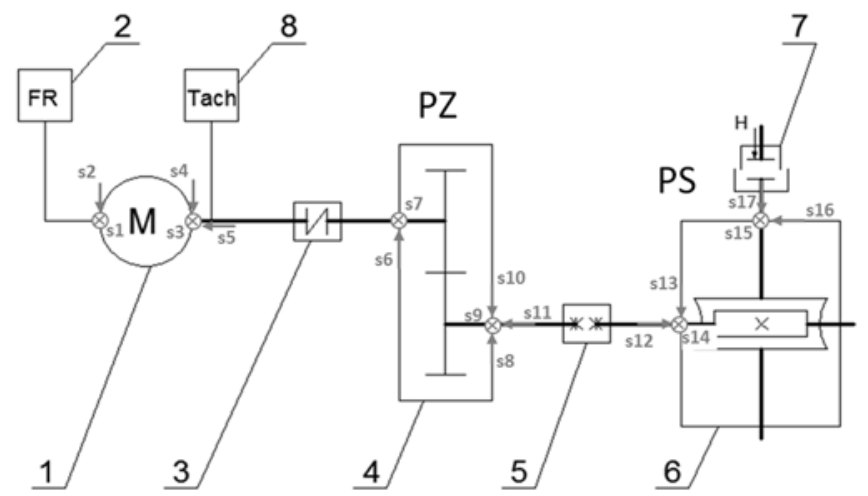

Fig. 2. Testing facility scheme with measuring points

numbers from s1 to 17 correspond to the numbers of the accelerometers installed.

\section{Measuring system and description of the diagnostic experiment}

Measurements of vibration and temperature of the bearing units of the testing rig were obtained using a specially built measuring system based on the PXI platform (PCI eXtension for Instrumentation). The platform was comprised of the PXI Trigger Bus which allows measurement synchronisation between individual measuring cards. The NI PXIe - 8133 type controller located in the NI PXIe - 1062Q housing was used. The following measuring cards were used:

- two NI PXI-4472B measuring cards - to measure vibration acceleration;

- NI PXI-4461 measuring card - to measure vibration acceleration and rotational speed;

- NI PXIe-6361 measuring card - to measure voltage and current intensity;

- NI USB-9211 cards - temperature measurement.

The data measuring algorithm was built in the LabVIEW environment. The multi-layered measuring structure allows for lossless multi-channel data acquisition. The measurement data was recorded 
simultaneously by the trigger buses (PXI Trigger Bus) used. The application structure was comprised of three basic layers prioritised, starting from the highest one: data acquisition, data writing to a file and user interface.

Measurements were performed for various rotational speeds of the input shaft $-100 \%, 75 \%$ and $50 \%$ of the electric motor nominal speed. To study the relationships between diagnostic parameters and load, for each of the speeds, vibrations were recorded for various values of the motor nominal load $-30 \%, 60 \%$ and $90 \%$. The measurements were performed for the aligned system and for misalignment between the motor and gear unit (the misalignment angle of $0.39^{\circ}$, shaft leng th $237 \mathrm{~mm}$ ), and between the gear and worm gear (the misalignment angle of $0.03^{\circ}$, shaft length $380 \mathrm{~mm}$ ). The degree of misalignment has been selected experimentally in a way that does not damage testing rig components. Misalignment was controlled using OPTALIGN laser shaft alignment system.

Based on $[5,15]$, the brake loading was calculated using a coefficient $\mu=0.4$ and pressure measurement in the brake pump. The brake torque value was: $\mathrm{M}_{\mathrm{H} 1}=36 \mathrm{Nm}, \mathrm{M}_{\mathrm{H} 2}=83 \mathrm{Nm}, \mathrm{M}_{\mathrm{H} 3}=111 \mathrm{Nm}$, corresponding to $30 \%, 60 \%$ and $90 \%$ of the motor load.

\section{Analysis of results}

The very popular analysis of RMS value of vibration represents a simple diagnostic indicator that carries information about the technical condition of the equipment. In most cases, this value increases when damage occurs. However, the RMS values of vibration calculated from the entire measurement range can also change in relation to the measured value for an undamaged system. Table 1 shows RMS values of vibration both in the case that the experimental rig is aligned properly and for the case that misalignment has been introduced between the motor and gear unit. It may be observed that certain values of RMS are smaller in the case of misalignment than in the equivalent healthy case. Such a case was noted for the sensors no. s6 and s7 arranged perpendicularly to the axis of the gear shaft. This decrease of RMS values may be due to the phenomenon of clearance elimination in rolling bearings operating under load caused by misalignment.

A similar situation can be found for the misalignment introduced to the shaft between the gear unit and worm gear. RMS values recorded with sensors s9, s10 and s14 decrease if misalignment has been introduced (Table 2).

Table 1. RMS values for a non-damaged facility and for the motor-gear misalignment introduced.

\begin{tabular}{||l|c|c|c|c|c|c||}
\hline \multicolumn{7}{|c|}{ RMS value [m/s $\mathrm{s}^{2}$} \\
\hline & \multicolumn{3}{|c|}{ No damage } & \multicolumn{3}{c||}{$\begin{array}{c}\text { Misalignment } \\
\text { motor-gear }\end{array}$} \\
\hline & $\begin{array}{l}\text { Load } \\
30 \%\end{array}$ & $\begin{array}{c}\text { Load } \\
60 \%\end{array}$ & $\begin{array}{c}\text { Load } \\
90 \%\end{array}$ & $\begin{array}{c}\text { Load } \\
\mathbf{3 0} \%\end{array}$ & $\begin{array}{c}\text { Load } \\
60 \%\end{array}$ & $\begin{array}{c}\text { Load } \\
\mathbf{9 0} \%\end{array}$ \\
\hline Sensor s2 & 3.59 & 3.52 & 3.83 & 4.34 & 4.06 & 4.53 \\
\hline Sensor s3 & 3.59 & 4.12 & 4.41 & 4.36 & 4.53 & 5.02 \\
\hline Sensor s4 & 3.11 & 2.96 & 2.99 & 3.77 & 3.56 & 3.95 \\
\hline Sensor 56 & 13.30 & 16.25 & 14.25 & 12.25 & 13.72 & 14.04 \\
\hline Sensor s7 & 19.65 & 19.86 & 18.77 & 14.17 & 14.61 & 13.12 \\
\hline
\end{tabular}

This can lead to erroneous evaluation of the technical condition, particularly in cases when only the RMS value of vibration recorded from a single sensor is analysed. Therefore, a method of signal analy-
Table 2. RMS values for a non-damaged facility and for the motor-worm gear shaft misalignment introduced.

\begin{tabular}{||l|c|c|c|c|c|c||}
\hline \multicolumn{5}{|c|}{ RMS value [m/s $\left.{ }^{2}\right]$} \\
\hline & $\begin{array}{c}\text { Load } \\
30 \%\end{array}$ & $\begin{array}{c}\text { Load } \\
60 \%\end{array}$ & $\begin{array}{c}\text { Load } \\
90 \%\end{array}$ & $\begin{array}{c}\text { Load } \\
30 \%\end{array}$ & $\begin{array}{c}\text { Load } \\
60 \%\end{array}$ & $\begin{array}{c}\text { Load } \\
90 \%\end{array}$ \\
\hline Sensor s8 & 10.85 & 10.90 & 10.14 & 13.84 & 12.41 & 12.52 \\
\hline Sensor s9 & 18.35 & 17.35 & 15.40 & 13.39 & 13.07 & 12.94 \\
\hline Sensor s10 & 13.30 & 14.46 & 14.71 & 17.11 & 17.60 & 18.26 \\
\hline Sensor s13 & 10.92 & 10.70 & 10.04 & 9.91 & 9.56 & 9.42 \\
\hline Sensor s14 & 10.80 & 10.53 & 9.91 & 9.60 & 9.27 & 9.26 \\
\hline \hline
\end{tabular}

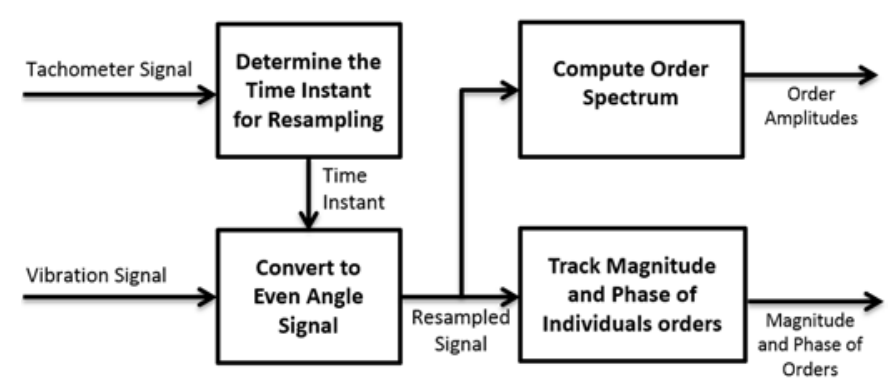

Fig. 3. Diagram of the order tracking analysis algorithm

sis based on order tracking analysis was proposed. The spectrum of orders is determined via a method based on resampling the vibration time signal in relation to the rotational speed of the input shaft. Fig. 3 shows the scheme of an algorithm for the order tracking analysis. In the first phase, the tachometer signal is interpolated with the cascaded integrator-comb (CIC) filter. Then, based on the filtered signal from the tachometer, a vibration signal resampling procedure is performed in order to determine the vibration signal in relation to the rotation angle (Even Angle Signal). The signal resampled this way can be processed with fast Fourier transform (FFT). Following the transform, instead of frequency, shaft order numbers are obtained which correspond to multiples of the rotational frequency of the input shaft [10].

In order to analyse the technical condition, order numbers corresponding to rotational speeds of individual shafts were determined. The measurement of rotational speed was performed by means of a tachometer generating one pulse per revolution of the input shaft between the motor and gear. Based on the measurement of vibration acceleration and rotational speed, the order spectrum was determined. The rotational frequency of the input shaft corresponds to order number 1 . Based on the gear ratio, the order number corresponding to the rotational frequency of the shaft between the gear and the worm gear is 0.74 . Shaft axial misalignment is the source of vibrations with double rotational frequency. These vibrations measured on the adjacent parts of the drive system are opposite in phase [3], caused by the deformation of the shaft misalignment. Considerations about the presence of higher harmonic of rotational frequency generated by geometrical non-linearity of objects were described in paper [7]. Realized measurements showed an amplitude increase of 2 and 3 multiples of rotational frequency. Therefore changes in the amplitude of the order no. 2 and 3 will be visible for the axial misalignment of the input shaft, while for the shaft between the gear, an amplitude change will be visible for orders number 1.48 and 2.22. 


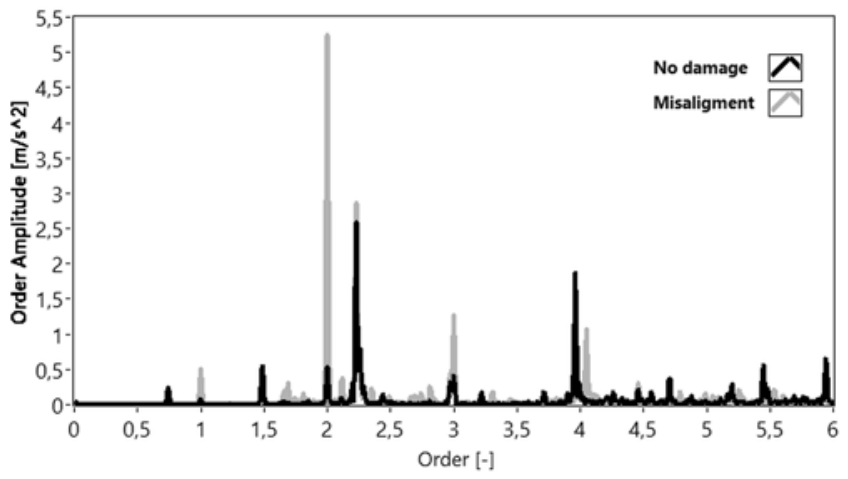

Fig. 4. Order Spectrum of acceleration signal-sensor no. s6 for the facility without damage (black) and with misalignment introduced between the motor and gear (grey) - rotational speed 75\%, load $60 \%$.

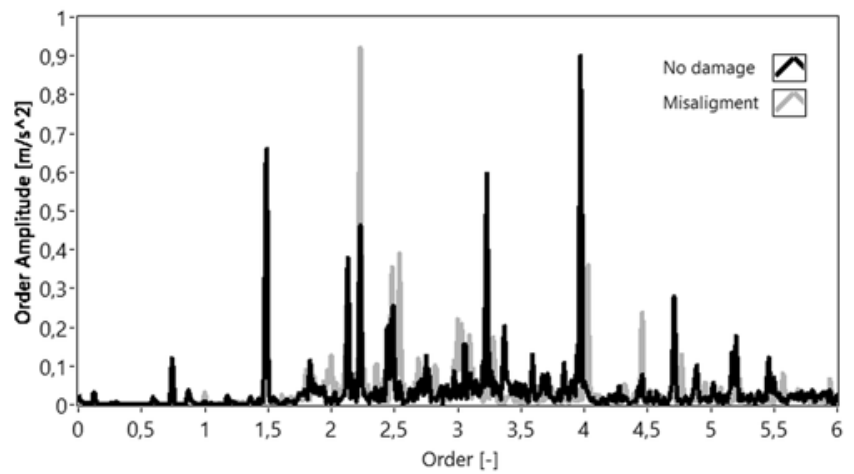

Fig. 5. Order spectrum of acceleration signal - sensor no. s13 for the facility without damage (black) and with misalignment introduced between the gear and worm gear (grey) - rotational speed 100\%, load 90\%

Fig. 4 shows the order spectrum of the acceleration signal recorded with the sensor s6. The order spectra for the cases of with and without misalignment between the motor and gear are given in grey and black respectively. A considerable amplitude increase can be observed for $2^{\text {nd }}$ order as well as the appearance of a band for the order no. 3 .

For the misalignment introduced to the shaft between the gear and worm gear, the amplitude of the order no. 2.22 can be observed to have doubled. This indicates the axial misalignment of the system (Fig. 5). It may be observed that the introduction of damage into the system will typically result in an increase in the amplitude of characteristic components in the order spectrum. A problem emerges, however, when the system operates with a different speed of the input shaft with the amplitudes of the characteristic components also changing with the rotational speed. In such a situation, it can be difficult to set alarm thresholds that are reliable and robust given variations in the rotational speed and system loading. Such a situation can be observed



Fig. 6. Amplitude of order no. 2 for different rotational speeds of the input shaft vs. loading of the undamaged system (black) and with damage introduced (grey) - sensor no. 57 in Fig. 6 which shows amplitudes of the order no. 2 for different rotational speeds and system load values. The order amplitude values cannot be clearly separated for the healthy and misalignment cases.

When analysing the technical condition of machines operating under variable conditions, the system loading values should be considered, since the amplitudes of the monitored parameters can be changed not only due to damages, but also due to changes in load. In this paper we adopt a similar approach to that which can be found in [1].

The method for scaling the order spectrum proposed by the authors requires the knowledge of amplitudes of the characteristic orders as a rotational speed function (in this case order no. 2, 3 and no. 1.48, 2.22). Such a function may be obtained by recording vibration signals and rotational speed during start-up and shut-down procedures. In the

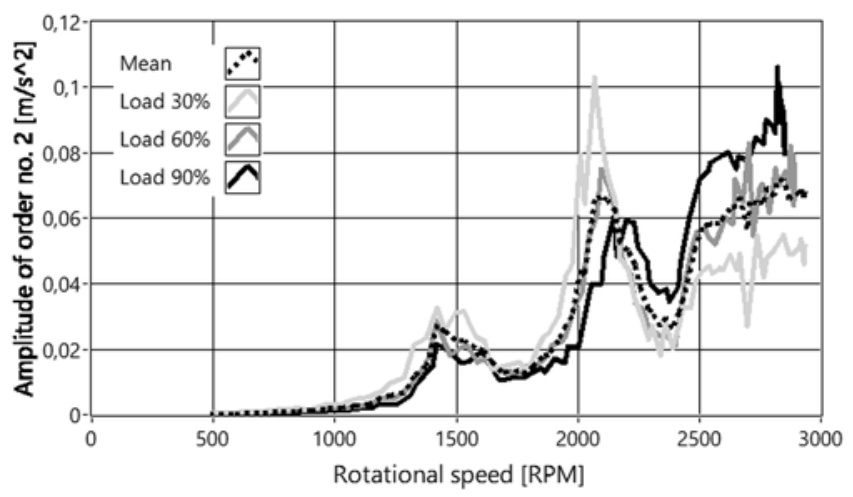

Fig. 7. Amplitude of order 2 as rotational speed function of the undamaged system - sensor no. s3 for different load: 30\% (light grey), 60\% (grey), $90 \%$ (black), mean value of the different loads (dotted line).

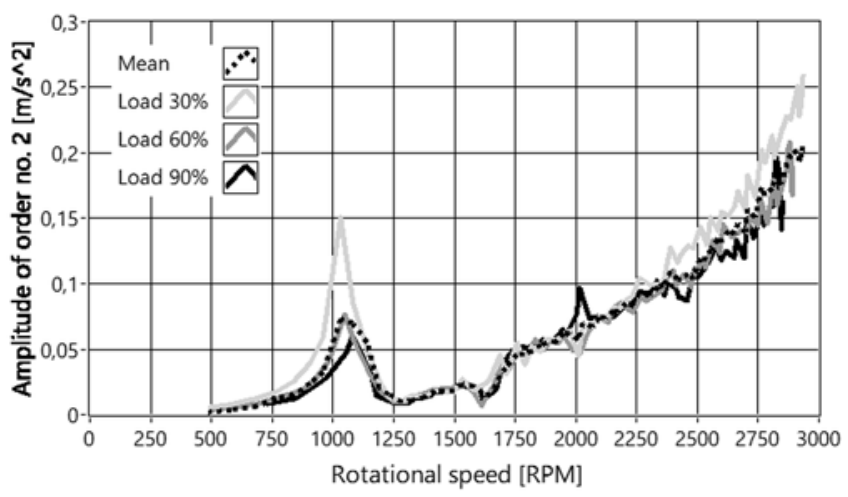

Fig. 8. Amplitude of order 3 as rotational speed function of the undamaged system - sensor no. 3 for different load: 30\% (light grey), 60\% (grey), 90\% (black), mean value of the different loads (dotted line).

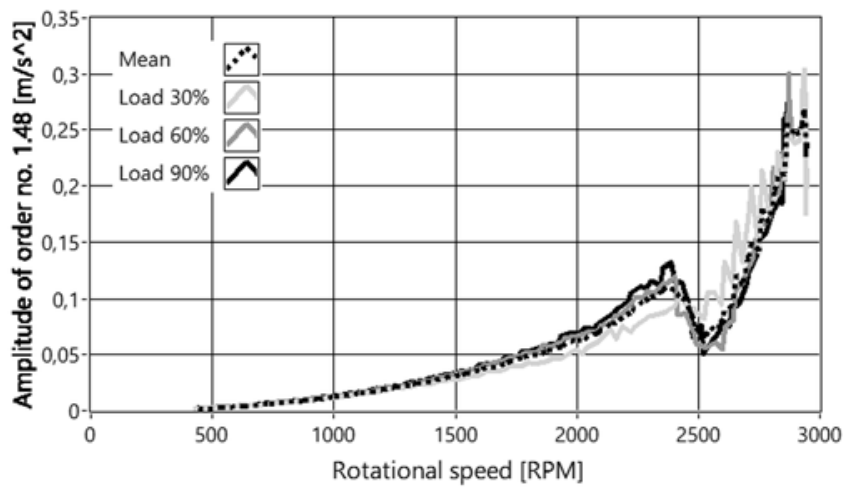

Fig. 9. Amplitude of order 1.48 as rotational speed function of the undamaged system - sensor no. s14 for different load: 30\% (light grey), $60 \%$ (grey), 90\% (black), mean value of the different loads (dotted line). 


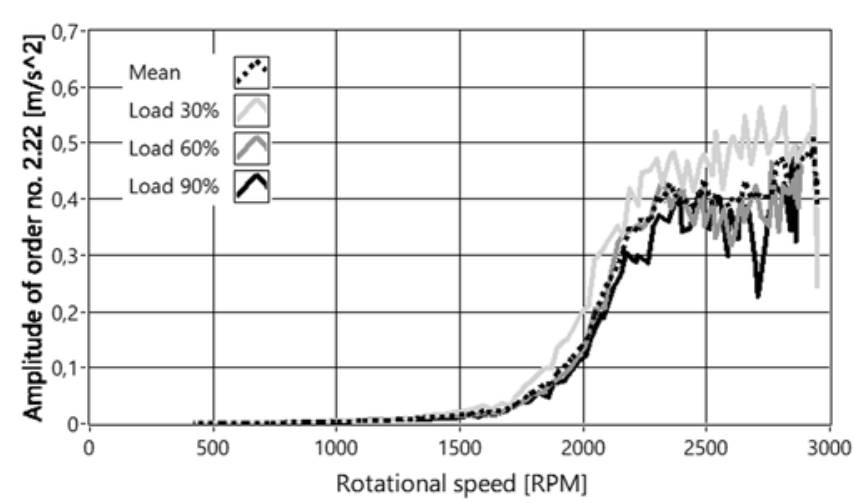

Fig. 10. Amplitude of order 2.22 as rotational speed function of the undamaged system - sensor no. s14 for different load: 30\% (light grey), 60\% (grey), 90\% (black), mean value of the different loads (dotted line).

Fig. 7, 8, 9, 10, the amplitudes of characteristic orders as a function of rotational speeds, for different loads is given.

On the basis of these characteristics the order amplitude for a given rotational speed can be determined for one of three preset load values. In some cases an increase in amplitude with increasing load may be observed, whilst in other cases the opposite is seen to be true. The mean value of the three characteristics for different values of the load was calculated (Fig. 7, 8, 9, 10 - dotted line), which greatly simplify the use of this method. The identified characteristics were used to determine reference values for the analyzed diagnostic parameters. Scaling amplitudes were performed according to the equation (1):

$$
A_{S}(n, r)=\frac{A(n, r)}{A_{G}(n, r)}
$$

where:

$$
\begin{aligned}
A_{S}(n, r)- & \text { scaled amplitude of } n \text {th order for rotational speed } \\
& \text { equal to } r ; \\
A(n, r)- & \text { order amplitude of } n \text {th order for rotational speed } \\
& \text { equal to } r ; \\
A_{G}(n, r)- & \text { mean amplitude for various load } n \text {th order for rota } \\
& \text { tional speed equal to } r \text { for the undamaged system; } \\
n & - \text { order index } \\
r & \text { - } \text { rotational speed value. }
\end{aligned}
$$

The above scaling method was implemented in LabVIEW environment and applied to measuring signals measured in three ranges of rotational speed: $100 \%, 75 \%, 50 \%$, and for each speed the order spectra were recorded. Fig. 11 shows the values of the amplitude scaled for the rotational speed and load. Separation of amplitude val-

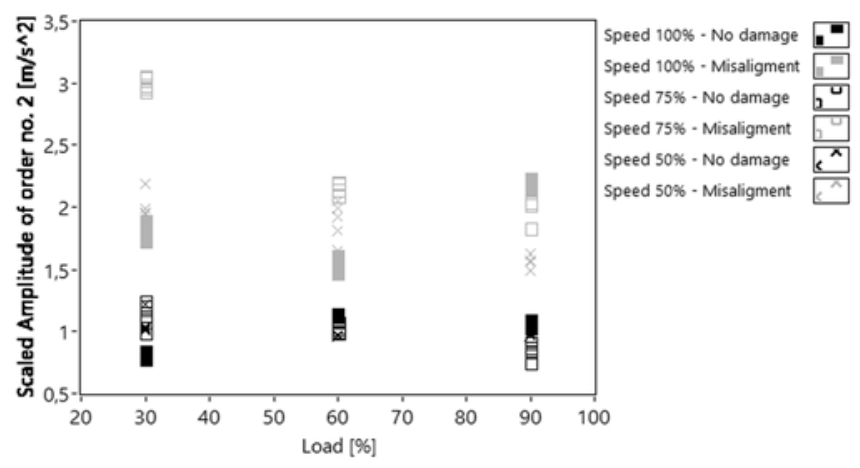

Fig. 11. Amplitude of order no. 2 for different rotational speeds of the input shaft vs. loading of the undamaged system (black) and with damage introduced (grey) - sensor no. s7.

\begin{tabular}{|c|c|c|c|c|c|}
\hline \multicolumn{6}{|c|}{$\begin{array}{l}\text { Misalignment } \\
\text { motor-gear }\end{array}$} \\
\hline & & & $\begin{array}{l}\text { Load } \\
30 \%\end{array}$ & $\begin{array}{l}\text { Load } \\
60 \%\end{array}$ & $\begin{array}{l}\text { Load } \\
90 \%\end{array}$ \\
\hline \multirow{6}{*}{ 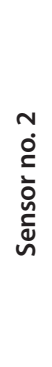 } & \multirow{3}{*}{ 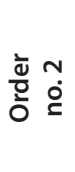 } & Speed $100 \%$ & 3.95 & 3.92 & 4.43 \\
\hline & & Speed $75 \%$ & 2.25 & 1.71 & 1.92 \\
\hline & & Speed $50 \%$ & 4.22 & 4.48 & 3.06 \\
\hline & \multirow{3}{*}{ 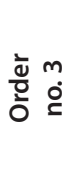 } & Speed $100 \%$ & 1.24 & 2.38 & 2.48 \\
\hline & & Speed $75 \%$ & 1.87 & 2.77 & 2.64 \\
\hline & & Speed $50 \%$ & 2.21 & 1.69 & 1.23 \\
\hline \multirow{6}{*}{ 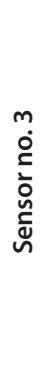 } & \multirow{3}{*}{  } & Speed $100 \%$ & 2.21 & 2.11 & 2.38 \\
\hline & & Speed $75 \%$ & 2.91 & 2.64 & 1.88 \\
\hline & & Speed $50 \%$ & 7.08 & 6.01 & 3.88 \\
\hline & \multirow{3}{*}{ 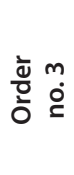 } & Speed $100 \%$ & 1.37 & 1.93 & 1.96 \\
\hline & & Speed $75 \%$ & 1.82 & 2.08 & 2.13 \\
\hline & & Speed $50 \%$ & 3.15 & 3.27 & 1.77 \\
\hline \multirow{6}{*}{ 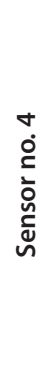 } & \multirow{3}{*}{ 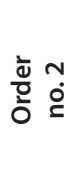 } & Speed $100 \%$ & 3.90 & 3.78 & 4.30 \\
\hline & & Speed $75 \%$ & 2.49 & 1.84 & 1.94 \\
\hline & & Speed $50 \%$ & 3.59 & 4.19 & 2.98 \\
\hline & \multirow{3}{*}{ 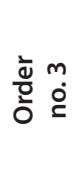 } & Speed $100 \%$ & 1.32 & 2.65 & 2.90 \\
\hline & & Speed $75 \%$ & 1.99 & 2.92 & 2.80 \\
\hline & & Speed $50 \%$ & 2.27 & 1.72 & 1.24 \\
\hline \multirow{6}{*}{ 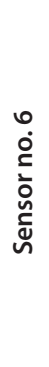 } & \multirow{3}{*}{ 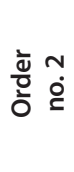 } & Speed $100 \%$ & 3.80 & 3.69 & 4.34 \\
\hline & & Speed $75 \%$ & 3.10 & 3.21 & 3.21 \\
\hline & & Speed $50 \%$ & 2.59 & 3.51 & 2.61 \\
\hline & \multirow{3}{*}{ 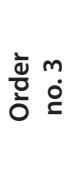 } & Speed $100 \%$ & 0.72 & 1.06 & 1.07 \\
\hline & & Speed $75 \%$ & 1.62 & 2.39 & 2.37 \\
\hline & & Speed $50 \%$ & 2.03 & 1.84 & 2.05 \\
\hline \multirow{6}{*}{ 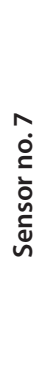 } & \multirow{3}{*}{ 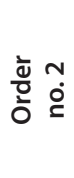 } & Speed $100 \%$ & 1.81 & 1.53 & 2.19 \\
\hline & & Speed $75 \%$ & 3.00 & 2.16 & 2.00 \\
\hline & & Speed $50 \%$ & 2.00 & 1.88 & 1.56 \\
\hline & \multirow{3}{*}{ 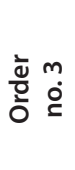 } & Speed $100 \%$ & 0.64 & 0.85 & 0.68 \\
\hline & & Speed $75 \%$ & 1.82 & 1.86 & 1.95 \\
\hline & & Speed $50 \%$ & 1.37 & 2.45 & 2.45 \\
\hline
\end{tabular}

ues between the undamaged condition (black) and the system with introduced damage (grey) can be noted.

Tables 3 and 4 provide the results of order tracking analysis for the damage introduced for measuring signals from sensors located perpendicularly to the axis of the shafts. The values are scaled order amplitudes specific for misalignment of the shafts. The results

Table 3. Scaled values of order amplitudes no. 2 and 3 for the facility with introduced misalignment of shaft between the motor and gear 
Table 4. Scaled values of order amplitudes no. 1.48 and 2.22 for the facility with introduced misalignment of shaft between the gear and worm gear.

\begin{tabular}{|c|c|c|c|c|c|}
\hline \multicolumn{6}{|c|}{$\begin{array}{c}\text { Misalignment } \\
\text { gear unit - worm gear }\end{array}$} \\
\hline & & & $\begin{array}{l}\text { Load } \\
30 \%\end{array}$ & $\begin{array}{l}\text { Load } \\
60 \%\end{array}$ & $\begin{array}{l}\text { Load } \\
90 \%\end{array}$ \\
\hline \multirow{6}{*}{ 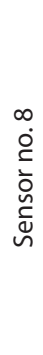 } & \multirow{3}{*}{ 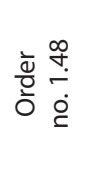 } & Speed $100 \%$ & 3.42 & 0.99 & 1.92 \\
\hline & & Speed $75 \%$ & 2.62 & 1.66 & 2.24 \\
\hline & & Speed $50 \%$ & 2.57 & 1.76 & 2.07 \\
\hline & \multirow{3}{*}{ 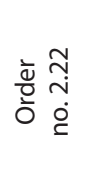 } & Speed $100 \%$ & 4.81 & 6.00 & 10.30 \\
\hline & & Speed $75 \%$ & 3.18 & 4.45 & 2.79 \\
\hline & & Speed $50 \%$ & 2.27 & 2.43 & 2.52 \\
\hline \multirow{6}{*}{$\begin{array}{l}a \\
\dot{0} \\
\subseteq \\
\vdots \\
\tilde{c} \\
\tilde{N}\end{array}$} & \multirow{3}{*}{ 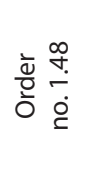 } & Speed $100 \%$ & 3.80 & 1.08 & 2.39 \\
\hline & & Speed $75 \%$ & 1.42 & 1.31 & 1.69 \\
\hline & & Speed $50 \%$ & 1.54 & 1.34 & 1.81 \\
\hline & \multirow{3}{*}{ 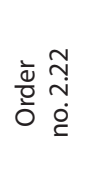 } & Speed $100 \%$ & 3.41 & 4.41 & 6.87 \\
\hline & & Speed $75 \%$ & 3.57 & 5.65 & 3.89 \\
\hline & & Speed $50 \%$ & 2.83 & 3.15 & 3.23 \\
\hline \multirow{6}{*}{$\begin{array}{l}\circ \\
\dot{0} \\
\stackrel{5}{0} \\
\dot{0} \\
\tilde{N} \\
\sim\end{array}$} & \multirow{3}{*}{ 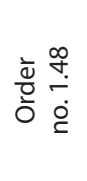 } & Speed $100 \%$ & 3.31 & 0.94 & 1.95 \\
\hline & & Speed $75 \%$ & 2.20 & 1.56 & 2.06 \\
\hline & & Speed $50 \%$ & 2.61 & 1.75 & 1.93 \\
\hline & \multirow{3}{*}{ 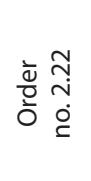 } & Speed $100 \%$ & 4.82 & 5.94 & 10.26 \\
\hline & & Speed $75 \%$ & 3.16 & 4.49 & 2.82 \\
\hline & & Speed $50 \%$ & 2.34 & 2.56 & 2.59 \\
\hline \multirow{6}{*}{$\begin{array}{l}m \\
\dot{m} \\
\dot{c} \\
\dot{0} \\
\tilde{\omega} \\
\sim\end{array}$} & \multirow{3}{*}{ 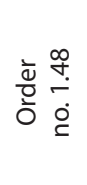 } & Speed $100 \%$ & 1.00 & 0.51 & 0.31 \\
\hline & & Speed $75 \%$ & 0.83 & 0.51 & 0.46 \\
\hline & & Speed $50 \%$ & 0.81 & 0.66 & 0.56 \\
\hline & \multirow{3}{*}{ 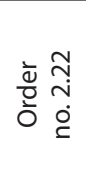 } & Speed $100 \%$ & 2.74 & 2.02 & 1.53 \\
\hline & & Speed $75 \%$ & 1.08 & 1.26 & 1.08 \\
\hline & & Speed $50 \%$ & 0.67 & 0.71 & 0.80 \\
\hline \multirow{6}{*}{ 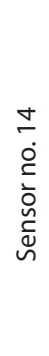 } & \multirow{3}{*}{ 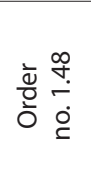 } & Speed $100 \%$ & 1.85 & 1.37 & 2.28 \\
\hline & & Speed $75 \%$ & 2.48 & 1.15 & 1.77 \\
\hline & & Speed $50 \%$ & 6.07 & 3.31 & 2.16 \\
\hline & \multirow{3}{*}{ 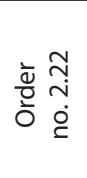 } & Speed $100 \%$ & 1.56 & 1.16 & 1.72 \\
\hline & & Speed $75 \%$ & 1.33 & 2.02 & 2.55 \\
\hline & & Speed $50 \%$ & 2.83 & 2.48 & 1.81 \\
\hline
\end{tabular}

should be interpreted in relation to value 1 which denotes the value of a scaled amplitude for the undamaged operating condition.

Analysing the above tables, an increase can be noted in the amplitude of determined diagnostic signals, which are the scaled content of the order amplitude. In some measuring points, this increase is sixfold and even ten-fold, which proves the usefulness of the method proposed for studying the misalignment of powertrain shafts.

In tables 3 and 4, values smaller than 1 are given as shaded fields. Interpretation of these values can lead to erroneous indication of the technical condition. This leads to a conclusion that it is essential to observe more than one diagnostic parameter in the analysed case.

\section{Summary}

The paper presents a method for evaluating the technical condition of powertrains operating at different rotational speeds and with varying load. To validate the method proposed, a diagnostic experiment was performed on a specially built testing rig. The experiment allowed shaft misalignment to be introduced between the motor and gear and between the cylindrical gear and the worm gear.

The results of analysis of the vibration acceleration signals proved the effectiveness of the method. The method for scaling values of amplitudes of characteristic orders does require the knowledge of order amplitude values for the undamaged machine, for individual operating conditions related to the rotational speed and load. This type of information can be obtained by recording vibration signals and the rotational speed during motor start-up and shut-down procedures. This method can also be used to diagnose other rotating machinery and other damages which symptoms are visible in the spectrum of the signal. Frequencies (orders) specific to the device and damage should be designated. The unbalance diagnosis, which is manifested by an increase in the amplitude of the first shaft order can be an example.

Monitoring the amplitude of the specific orders, scaled for the load and rotational speed, carries more information than monitoring of such parameters as RMS value calculated over the entire measuring range. The method proposed can be applied for diagnosing other types of damage that are characterised by the change of the specific frequency amplitude.

\section{References}

1. Bartelmus W, Zimroz R. A new feature for monitoring the condition of gearboxes in non-nonstationary operation conditions. Mechanical Systems and Signal Processing 2009; 23(5): 1528-1534, http://dx.doi.org/10.1016/j.ymssp.2009.01.014.

2. Braun S, Seth B B. On the extraction and filtering of signals acquired from rotating machines. Journal of Sound and Vibration 1979; 65(1): 37-50, http://dx.doi.org/10.1016/0022-460X(79)90526-1. 
3. Cempel C. Diagnostyka Wibroakustyczna Maszyn, Warszawa: PWN, 1989.

4. Cioch W, Knapik O, Leśkow J, Finding a frequency signature for a cyclostationary signal with applications to wheel bearing diagnostics, Mechanical Systems and Signal Processing. spec. iss.: Condition monitoring of machines in non-stationary operations 2013; 38(1): 55-64.

5. Gajek A. Szczypiński-Sala W. Wybrane własności tribologiczne okładzin ciernych hamulców tarczowych, Archiwum Motoryzacji 2012; 57(3): 119-132.

6. Hines J W, Jesse S, Kuropatwinski J, Carley T, Kueck J, Nower D, Hale F. Motor Shaft Alignment Versus Efficiency Analysis, P/PM Technology 1997; October: 10-13.

7. Lees A W. Misalignment in rigidly coupled rotors, Journal of Sound and Vibration 2007; 305(1-2): 261-271, http://dx.doi.org/10.1016/j. jsv.2007.04.008.

8. Lenart L, Leśkow J, Synowiecki R., Subsampling in estimation of autocovariance for periodically correlated time series, Journal of Time Series Analysis 2008; 29(6): 995-1018, http://dx.doi.org/10.1111/j.1467-9892.2008.00591.x.

9. McFadden P. D. Examination of a technique for the early detection of failure in gears by signal processing of the time domain average of the meshing vibration, Mechanical systems and signal processing 1987; 1(2): 173-183, http://dx.doi.org/10.1016/0888-3270(87)90069-0.

10. National Instrument. LabVIEW Order Analysis Toolkit User Manual. 2005.

11. Ottewill J R, Orkisz M. Condition monitoring of gearboxes using synchronously averaged electric motor signals. Mechanical Systems and Signal Processing 2013; 38(2): 482-498, http://dx.doi.org/10.1016/j.ymssp.2013.01.008.

12. Pan M C, Chiu C C. Investigation on improved Gabor order tracking technique and its applications, Journal of Sound and Vibration 2006; 295(3-5): 810-826, http://dx.doi.org/10.1016/j.jsv.2006.01.046.

13. Randall R B. Frequency Analysis. Denmark: Bruel \& Kjær, 1987.

14. Shao H, Jin W, Qian S. Order tracking by discrete Gabor expansion, IEEE Transactions on Instrumentation and Measurement 2003; 52(3): 754-761, http://dx.doi.org/10.1109/TIM.2003.814670.

15. Studziński K. Collective work: Techniczny poradnik samochodowy - part II. Warszawa: WNT, 1962.

16. Stander C J, Heyns P S, Schoombie W. Using vibration monitoring for local fault detection on gears operating under fluctuating load conditions, Mechanical Systems and Signal Processing 2002; 16(6): 1005-1024, http://dx.doi.org/10.1006/mssp.2002.1479.

17. Qi X, Yuan Z, Han X. Diagnosis of misalignment faults by tacholess order tracking analysis and RBF networks, Neurocomputing 2015; 169: 439-448, http://dx.doi.org/10.1016/j.neucom.2014.09.088.

\section{Paweł PAWLIK}

AGH University of Science and Technology, Department of Mechanics and Vibroacoustics, al. A. Mickiewicza 30, 30-059 Kraków, Poland

\section{Dariusz LEPIARCZYK Rafał DUDEK}

AGH University of Science and Technology, Department of Machine Design and Technology, al. A. Mickiewicza 30, 30-059 Kraków, Poland

\section{James R. OTTEWILL \\ Paweł RZESZUCIŃSKI \\ Mariusz WÓJCIK \\ Agnieszka TKACZYK}

ABB Corporate Research Center, ul. Starowiślna 13 A, 31-038 Kraków, Poland

E-mails: pawlik@agh.edu.pl, ledar@agh.edu.pl,dudraf@agh.edu.pl, james.ottewill@pl.abb.com, pawel.rzeszucinski@pl.abb.com, mariusz.wojcik@pl.abb.com, agnieszka.tkaczyk@pl.abb.com 